\title{
Education, work participation and income in Agriculture Industri In Indonesia
}

\author{
Benjamin Drean \\ (Lycée George Sand, EPL du Velay) \\ Bambang Hadi Prabowo \\ (STIE Jaya Negara Tamansiswa Malang)
}

\begin{abstract}
This study examines the relationship of agricultural education in encouraging work participation in agriculture which in turn can increase the aggregate income of people who work in agriculture as indicated by an increase in Employment Income in Agriculture in Indonesia. To achieve this goal, the Quantitative Threshold Autoregressive method is used to predict the behavior of the data so that the behavior of the relationship between the data can be seen and can be seen the growth of community income and work participation in agriculture with education as the driving factor. The hope is that knowing past behavior data can be an indicator of decisions that can be taken in the future. We found that Education in agriculture is an effort to increase human resources in agriculture. Agriculture with a lot of potentials needs to be empowered and developed. Where agriculture can absorb labor and improve welfare in Indonesia.
\end{abstract}

Keywords: Agriculture, Education, Income

\section{Introduction}

Currently, the agricultural sector in Indonesia is still a space for the people. Approximately 100 million people or nearly half of the total Indonesian people work in the agricultural sector (Soetiono,2021). For this reason, the Ministry of Agriculture has made various efforts to foster small and medium enterprises to become a strong foundation in supporting the Indonesian economy. Agriculture, especially food security, still relies on the medium to a small level. Small-medium enterprises in Indonesia can provide a strong foundation in agriculture (Putra \& Santoso,2020). With a population of more than 200 million people in 2020 and the problem of food is a sector that is always needed by humans, especially consumers in Indonesia which are very large, making the agricultural sector a sector that has the potential to develop in Indonesia (Madduppa et al,2021). Agricultural development and food security in Indonesia today and in the future face many problems including climate change, population growth, and a decrease in the number of workers in the agricultural sector. On the other hand, Indonesia has abundant natural resources, advanced technology that continues to develop, and a more friendly climate, namely a tropical climate that has the opportunity to make problems such as population growth a solution, namely increasing human resources, considering that the agricultural sector is one of the sectors that absorbs a lot of labor (Purwanto et al,2021). 
The Indonesian government through the Ministry of Agriculture continues to encourage the application of agricultural mechanisms. In addition, the Ministry of Agriculture has also transformed the College of Agricultural Extension into an Agricultural Development Polytechnic. These steps have the potential to convert unemployed human resources into quality human resources to meet the future needs of Agricultural Human Resources while at the same time attracting the interest of the younger generation to enter agriculture. The Indonesian government's efforts to attract young people to agriculture, in addition to modernizing agriculture, agricultural development must be oriented towards the Planting Industry, which is managed from upstream to downstream, so that it makes farmers less lazy to work and more prestigious. Indonesia is a very strategic country for agriculture because Indonesia has an abundance of sunshine, lots of rain, and no less workforce (large population). As an archipelagic country and has a large area, Indonesia is a country that is endowed with endless natural resources. From natural beauty for tourism to natural wealth that can be produced into separate energy sources, one of which comes from the agricultural sector (Iswara,2020). Since a long time ago, Indonesia has always been rich in agricultural products such as rice, soybeans, corn, peanuts, cassava, and sweet potatoes. In addition, there are also products from agriculture which are referred to as agricultural products of trade crops, namely tea, coffee, coconut, quinine, cloves, sugar cane, rubber, and others. With Indonesian agriculture getting bigger and bigger, this has a positive impact too. Not only for domestic affairs but also for foreign affairs. The Indonesian agricultural sector in the eyes of the world has received a positive response that should be proud of since hundreds of years ago (Touwen,2021). Indonesia, which is known for its spices, has made Indonesia a country that has the potential to develop in agriculture. This study examines the agricultural sector in terms of human resources, namely education, work participation, and income of agricultural entrepreneurs in the territory of the Republic of Indonesia.

\section{Literature Review}

Indonesia is an agrarian country that gives consequences for the growth of almost the entire life of Indonesian society, hence the need for the attention of the government to a strong and resilient agricultural sector. Therefore, one of the sectors that support economic growth is the agricultural sector (Nurrochmat et al,2020). Indonesia is an agricultural country, which means that farmers play a very important role in the overall national economy of Indonesia. This is shown by a large number of people or workers in the agricultural sector. Farmers and agriculture are the major bases of the Indonesian economy. If only this agribusiness system could get attention from the government, then we could be independent in terms of fulfilling the population's foodstuffs. The government's attention includes supporting the agricultural sector in the fields of research and technology that are commensurate.

The agricultural sector in Indonesia is still an important aspect as a driving force for the country's economy. This is because agriculture in terms of production is the second most influential sector after the processing industry. Meanwhile, when compared to other sectors, agriculture is still in the top position in addition to the trade sector and the construction sector. Thus, the agricultural sector is able to raise Indonesia's image in the eyes of the world, especially as a fairly productive agricultural country (Payumo et al,2014). Apart from benefiting from favorable climatic conditions and natural resources, agriculture in Indonesia is also supported by its human resources. Many farmers still hold and use conventional methods in terms of determining crops, weather, harvest, and post-harvest. This method has been around for a long time and has been carried out from generation to generation until now. The transfer of agricultural technology is also not an obstacle for farmers. In fact, the existence of agricultural technology makes it easier for farmers and more synergized. Therefore, it is hoped that in the future, the 
farmer profession will no longer be underestimated. Agriculture in Indonesia also has opportunities and challenges that must be faced (Moeis et al,2020). Seeing how big the development of agriculture in Indonesia is, it is a potential that must be maximized by all parties. Be it by farmers, actors in agriculture, and the government. Support from the government can be done by providing guidance to farmer groups and providing various best agricultural products such as superior seeds, fertilizers, and so on. Even though agricultural development in Indonesia has prospects and is running very well to date, it does not mean that there are no challenges. It is precisely the increase in agricultural potential, the government and agricultural sector actors must be better prepared to face challenges in an era of advances in information technology. Some of the challenges include human resource development in the agricultural sector (Durand \& Fournier,2017). Agricultural development in Indonesia has been going well. However, there are still some challenges to be faced. With cooperation and collaboration between stakeholders and agricultural sector actors, it is not impossible that Indonesian agriculture will develop in an increasingly positive direction.

\section{Research Methods and Materials}

This study examines the relationship of agricultural education in encouraging work participation in agriculture which in turn can increase the aggregate income of people who work in agriculture as indicated by an increase in Employment Income in Agriculture in Indonesia. To achieve this goal, the Quantitative Threshold Autoregressive method is used to predict the behavior of the data so that the behavior of the relationship between the data can be seen and can be seen the growth of community income and work participation in agriculture with education as the driving factor. The hope is that knowing past behavior data can be an indicator of decisions that can be taken in the future. In this study we used the autoregressive equation as follows:

$\mathrm{AR}_{(\mathrm{p})}=\mathrm{Y}_{\mathrm{t}}=\mathrm{c}+\Phi_{1} \mathrm{Y}_{\mathrm{t}-1}+\Phi_{2} \mathrm{Y}_{\mathrm{t}-2}+\ldots . .+\Phi_{\mathrm{p}} \mathrm{Y}_{\mathrm{t}-\mathrm{p}}+\mathrm{e}_{\mathrm{t}}$

Where AR is $\mathrm{Y}$ and $\mathrm{Yt}$ is $\mathrm{Y}$ over time in a time series which is influenced by Yt-1 or Y over time in the past in period 1 and Yt-1 itself is also influenced by Yt-2 which is $\mathrm{Y}$ in the past in the period 2 and so on which is influenced by et which is the error term for the time in the study period. This study focuses on secondary data sourced from the world bank including Indonesia employment income in agriculture in Indonesia data, education investment in Agriculture in Indonesia and employment in agriculture in Indonesia. With the econometric equation as follows:

$Y_{t}=\beta_{0}+\beta_{1} P_{t 1}+\beta_{2} E_{t 2}+e_{t}$

Where $\mathrm{Y}$ is a employment income in agriculture, $\mathrm{t}$ is a time period, $\beta$ is constant, $\mathrm{P}$ is work participation in agriculture or employment in agriculture, $\mathrm{E}$ is education investment in agriculture, and e is error term. All data are secondary data from world banks.

\section{Results and Discussion}

In analyzing the threshold variable, the employment income in agriculture variant is used as an indicator of people's income growth in the agriculture sector, Employment in agriculture as work participation in the agricultural sector, and education as an indicator of educational investment. Employment income in agriculture, Employment in agriculture, and health as the threshold variable. 
Meanwhile, the non-threshold variable is education. The following are the estimation results that we have done:

EMPLOYMENT_INCOME_IN_AGRICULTURE $=(-71042215918.4+$ $179381853633 *$ EMPLOYMENT_IN_AGRICULTURE) + $(215156626722$ 358861884660*EMPLOYMENT_IN_AGRICULTURE)*@LOGIT(3.92672764498e-10*(EMPLOY MENT_INCOME_IN_AGRICULTURE(-3)-43131354156.4)) + 2.57871189995*EDUCATION

The estimation results from the first estimate can be seen in table 1 below:

Table 1. Estimation Result

\begin{tabular}{|c|c|c|c|c|}
\hline Variable & Coefficient & Std. Error & t-Statistic & Prob. \\
\hline \multicolumn{5}{|l|}{ Threshold Variables (linear part) } \\
\hline $\mathrm{C}$ & $-7.10 \mathrm{E}+10$ & $1.21 \mathrm{E}+11$ & -0.587974 & 0.5696 \\
\hline EMPLOYMENT_IN_AGRICULTURE & $1.79 \mathrm{E}+11$ & $2.50 \mathrm{E}+11$ & 0.716657 & 0.49 \\
\hline \multicolumn{5}{|l|}{ Threshold Variables (nonlinear part) } \\
\hline $\mathrm{C}$ & $2.15 \mathrm{E}+11$ & $1.19 \mathrm{E}+11$ & 1.808417 & 0.1007 \\
\hline EMPLOYMENT_IN_AGRICULTURE & $-3.59 \mathrm{E}+11$ & $2.45 \mathrm{E}+11$ & -1.466927 & 0.1731 \\
\hline \multicolumn{5}{|l|}{ Non-Threshold Variables } \\
\hline EDUCATION & 2.578712 & 0.372957 & 6.91423 & 0 \\
\hline \multicolumn{5}{|l|}{ Slopes } \\
\hline SLOPE & $3.93 \mathrm{E}-10$ & $3.71 \mathrm{E}-10$ & 1.058294 & 0.3148 \\
\hline \multicolumn{5}{|l|}{ Thresholds } \\
\hline THRESHOLD & $4.31 \mathrm{E}+10$ & $5.87 \mathrm{E}+09$ & 7.353365 & 0 \\
\hline R-squared & 0.996827 & \multicolumn{2}{|c|}{ Mean dependent var } & $9.49 \mathrm{E}+10$ \\
\hline Adjusted R-squared & 0.994924 & \multicolumn{2}{|c|}{ S.D. dependent var } & $3.86 \mathrm{E}+10$ \\
\hline S.E. of regression & $2.75 \mathrm{E}+09$ & \multicolumn{2}{|c|}{ Akaike info criterion } & 46.59834 \\
\hline Sum squared resid & $7.55 \mathrm{E}+19$ & \multicolumn{2}{|c|}{ Schwarz criterion } & 46.94143 \\
\hline Log likelihood & -389.0859 & \multicolumn{2}{|c|}{ Hannan-Quinn criter. } & 46.63244 \\
\hline F-statistic & 523.6398 & \multicolumn{2}{|c|}{ Durbin-Watson stat } & 1.89381 \\
\hline Prob(F-statistic) & 0 & & & \\
\hline
\end{tabular}

Source : Data world Bank Compiled

It can be seen that the relationship between Employment Income in Agriculture and education and Employment in Agriculture is positive with a value of 1.79E + 11 for Employment in Agriculture and 2.578712 for education, which means an increase in education investment in agriculture by $2.5 \%$ followed by an increase in work participation by 1, 79\% and encourages the average income of agricultural workers by $1 \%$ as indicated by an increase in Employment Income in Agriculture.

This shows that investment in education can boost people's income in general. However, in non-linear estimates, the relationship between work participation and community income in agriculture is negative at $-3.59 \mathrm{E}+11$ with a t-statistic of -1.466927 . This indicates that an increase in income can encourage investment in education requiring a sacrifice of costs before increasing income. These cost sacrifices are in the form of education and training costs in agriculture, including the cost of equipment 
and technology to increase agricultural production which in turn increases income in agriculture. When investment in education is made, the population goes to school or train so that work participation decreases. The greater the investment in education in the education investment process, of course, it takes time, in the process, there is a decrease in work participation. However, after the education investment process is complete, there will be an increase in work participation followed by an increase in wages or income, according to non-linear estimates. All estimation results are greater than the t-statistic, which means that the results obtained from the estimation are significant. To determine the behavior of data in influencing Employment Income in Agriculture, the prediction of the effect of investment in agricultural education is presented in the following graph:

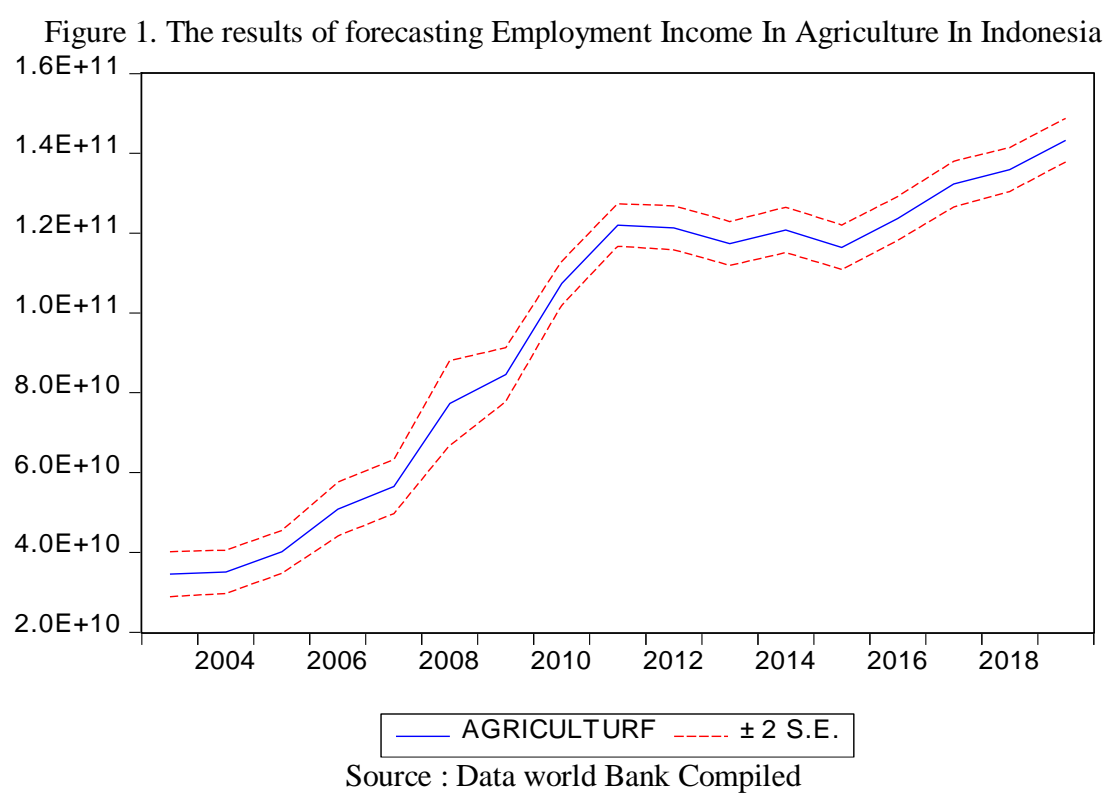

From the forecast results shown in Figure 1, it can be seen that the Employment Income in Agriculture graph tends to increase from time to time and fluctuates. These fluctuations represent fluctuations in the education process and fluctuations in work participation as a result of educational investment. However, in the end, it will increase the aggregate income of the community so that the welfare of the people can be better, especially those who work in agriculture.

\section{Conclusions}

Education in agriculture is an effort to increase human resources in agriculture. Agriculture with a lot of potentials needs to be empowered and developed. Where agriculture can absorb labor and improve welfare in Indonesia.

\section{References}

Durand,C., Fournier,S.(2017).Can Geographical Indications Modernize Indonesian and Vietnamese Agriculture? Analyzing the Role of National and Local Governments and Producers' Strategies. World Development,Volume 98, October 2017, Pages 93-104.https://doi.org/10.1016/j.worlddev.2015.11.022 
Iswara,M.A.(2020).A Land Without Farmers Indonesia's agricultural conundrum.thejakartapost.com. Retrieved April 8, 2021 (actual access date),from : https://www.thejakartapost.com/longform/2020/08/13/a-land-without-farmers-indonesias-agriculturalconundrum.html

Madduppa,H., Bahri,S., Ghozali,A.T., Atmadipoera,A.S., Subhan,B., Santoso,P., Natih,I.N.M., Arafat,D.(2021).Population genetic structure of Olive ridley (Lepidochelys olivacea) across Indonesian archipelago revealed by mitochondrial DNA: Implication for management.Regional Studies in Marine Science,[Online], https://doi.org/10.1016/j.rsma.2020.101600

Moeis,F.R., Dartanto,T., Moeis,J.P., Ikhsan,M.(2020).A longitudinal study of agriculture households in Indonesia: The effect of land and labor mobility on welfare and poverty dynamics. World Development Perspectives, Volume 20, December 2020, 100261. https://doi.org/10.1016/j.wdp.2020.100261

Nurrochmat,R.D., Boer,R., Ardiansyah,M., Immanuel,G., Purwawangsa,H. (2020). Policy forum: Reconciling palm oil targets and reduced deforestation: Landswap and agrarian reform in Indonesia. Forest Policy and Economics,Volume 119, October 2020, 102291.https://doi.org/10.1016/j.forpol.2020.102291

Payumo,J.G., Arasu,P., Fauzi,A.M., Siregar,I.Z., Noviana,D. (2014). An entrepreneurial, research-based university model focused on intellectual property management for economic development in emerging economies: The case of Bogor Agricultural University, Indonesia.World Patent Information, Volume 36, March 2014, Pages 22-31. https://doi.org/10.1016/j.wpi.2013.11.009

Purwanto,A., Sušnik,J., Suryadi,F.X., Fraiture,C.d. (2021). Quantitative simulation of the water-energy-food (WEF) security nexus in a local planning context in indonesia. Sustainable Production and Consumption Volume 25, January 2021, Pages 198-216. https://doi.org/10.1016/j.spc.2020.08.009

Putra,P.O.H., Santoso,H.B.(2020).Contextual factors and performance impact of e-business use in Indonesian small and medium enterprises (SMEs).Heliyon,[Online First],https://doi.org/10.1016/j.heliyon.2020.e03568

Soetiono,K.S.(2021).Investment Without Leaving Home: TaniHub and Digital Farmers. ibs.ac.id. Retrieved April 8, 2021 (actual access date), from: http://ibs.ac.id/en/investment-without-leaving-home-tanihub-and-digital-potential/

Touwen,J.(2021).The Economic History of Indonesia.Retrieved April 8, 2021 (actual access date), from :https://eh.net/encyclopedia/the-economic-history-of-indonesia/ 